\title{
СТРОЕНИЕ И ПАЛЕОНТОЛОГИЧЕСКАЯ ХАРАКТЕРИСТИКА КЕЛЛОВЕЙСКИХ ОТЛОЖЕНИЙ НА СЕВЕРЕ ДОНО-МЕДВЕДИЦКИХ ДИСЛОКАЦИЙ
}

\section{В.Ф. Салтыков}

\author{
Научно-исследовательский институт естественных наук \\ Саратовского государственного университета, \\ отделение геологии \\ E-mail: dekanat@geol.sgu.ru
}

Приводятся новые материалы по литологическому составу отложений, характеру границ между выделенными стратонами келловея и палеонтологическому обеспечению их возраста, собранные при изучении керна скважин, пробуренных на севере Доно-Медведицких дислокаций. Анализ полученных сведений позволил произвести расчленение отложений на уровне подсвит в новом районе Нижнего Поволжья. Они соответствуют аммонитовым зонам стандарта и характеризуются собственными фораминиферовыми комплексами. В подошве каждой свиты присутствуют опесчаненные глины, тогда как границы между подсвитами проводятся по палеонтологическим данным в сравнительно однородном глинистом разрезе.

The Composition and Paleontologic Characteristics of the Callovian Depositions from the North of the Don-Medveditsa Dislocations

\section{V.F. Saltykov}

New materials on the lithologic composition, character of the boundaries between the subsuites and paleontologic age determinations are presented. Those were obtained upon stydying the well copes from the North of the Don-Medveditsa Dislocations. The data analysis has allowed to divide the depositions in new place of the Volga Region in subsuites. Those are corresponding to standart ammonite zones and peculiar for foraminifer assemblages of their own. Sandy clays occur in subsuite bottom, the boundaries between subsuites are drawn from paleontologic data in clayey section.

\section{Введение}

Келловейские отложения широко распространены на территории Поволжья. Они достаточно подробно изучались длительное время в ряде опорных разрезов как в естественных выходах, преимущественно расположенных на площади Саратовского Правобережья, где расчленение производилось прежде всего по аммонитам, так и в скважинах, где исследовалась главным образом микрофауна. Увязка макро- и микрофаунистической зональностей осуществлялась благодаря совместному нахождению аммонитов и фораминифер в некоторых разрезах, в частности в Малиновом овраге (Саратовская область).

В последнем обнажении расположен классический разрез, который принимается в качестве стратотипического для расчленения келловея на юге Русской платформы. Используя собранные материалы, В.Г.Камышева-Елпатьевская с коллегами [1] создали биостратиграфическую схему келловея. Впоследствии она была несколько модернизирована [2]. Затем этот разрез изучался рядом исследователей [3-6]. На основе этих данных произведено выделение местных подразделений $[7,8]$. В келловейском ярусе, по предложению А.Г.Олферьева, выделена курдюмская серия в объеме трех подъярусов и шести аммонитовых зон. В свою очередь, она делится на три свиты, соответствующие по объему подъярусам (снизу вверх): хлебновскую $\mathrm{J}_{2} \mathrm{hl}$, докучаевскую $\mathrm{J}_{2} \mathrm{dk}$ и малиновоовражную $\mathrm{J}_{2} \mathrm{mo}$.

Первая из них (слои 1 и 2 [5] или слои 2-5 [3]) сложена серыми некарбонатными алевритистыми глинами с глинисто-карбонатными конкрециями. В основании отмечаются глинистые алевролиты, залегающие на алевритах каменноовражной свиты среднего бата. Мощность $\mathrm{J}_{2} \mathrm{hl}$ составляет 23 м, но в работе [5] приводится величина 33,5 м. Возраст отложений обоснован аммонитами, принадлежащими к обеим зонам нижнего келловея. Докучаевская свита принята по стратотипу в Нижегородской области - обнажение у с. Докучаево [9]. Она сложена серыми известковистыми глинами с прослоями алевролитов и известковистых конкреций мощностью 9,5 м (однако в тексте статьи [7] указывается величина 17 м, которая, как и фауна, очевидно, свойственна стратотипу, а не рассматриваемому разрезу, но этот момент авторы не акцентируют). Авторы [7] не отмечают присутствие отложений среднего келловея в Малиновом овраге, хотя в работах [1-4] были обнаружены зональные аммониты. Малиновоовражная свита (слои 5 и 6 [5] или слои 7 и 8 [3]) представлена известковистыми тонкоплитчатыми глинами с прослоями известняков мощностью до 30 м (на рисунке в статье [7] указана мощность 6 м, которая близка к данным С.В.Мелединой [5], но не совпадает с величинами С.Н.Алексеева и Ю.С.Репина [3] - 9,6 м). Подробно совпадения и противоречия в интерпретации фактических материалов различными исследователями рассматриваются в статье [10].

Приведенные сведения плохо согласуются с требованиями Стратиграфического кодекса [11], предъявляемыми к описанию стратотипических и опорных разрезов, прежде всего, из-за чрезмерной лаконичности литологической характеристики и отсутствия полного состава фаунистических остатков и их точного расположения по разрезу. Только обозначены условия залегания свит по принципу низ - верх без должного описания. 
Не вполне понятна путаница с величинами мощностей. Фактически, свиты лишь названы на основе биостратиграфической информации С.В.Мелединой, причем ее биостратоны, соответствующие аммонитовым зонам, объединяются в каждой выделенной свите. Нарушен критерий комплексности обоснования местных подразделений [11]. Не учтены разногласия между интерпретациями различных исследователей по поводу стратиграфического положения пород в одном и том же разрезе. Стратотипы с такими характеристиками вряд ли могут служить эталоном для последующего сравнения с отложениями в других районах Поволжья.

Краткость описания вещественного состава отложений (преимущественно глин) и отсутствие диагностических различий между свитами привели к давно известной степени расчленения келловея, только подъярусы стали называться свитами. Между тем имеющаяся биостратиграфическая информация позволяет детализировать расчленение отложений в данном опорном разрезе, по крайней мере на уровне подсвит, которые будут соответствовать аммонитовым зонам. Кроме того, к их характеристике следует добавить состав фораминиферовых комплексов, описанных Г.Н.Старцевой и Т.Н.Хабаровой при изучении пород в Малиновом овраге [12].

В настоящее время происходит ревизия биостратиграфического расчленения келловея (особенно нижнего подъяруса), начатая Дж. Калломоном с коллегами $[13,14]$. Эти результаты уже отражены в последнем аммонитовом стандарте [15]. Для Русской платформы подобная работа выполнена В.В.Миттой [16-18], Д.Б.Гуляевым [19], Д.Н.Киселевым [20], которые показали необходимость выделения трех (а не двух, как в [9]) аммонитовых зон (снизу вверх): herveyi, koenigi, calloviense. Ю.С.Репин и Н.Х.Рашван считают, что в разрезе Малинового оврага присутствует самая нижняя зона herveyi [6]. Находка В.Б.Сельцером в Елшанском разрезе (к югу от Малинового оврага) характерных для нее аммонитов подтверждает это положение [21].

Изложенные сведения дают основание для более дробного расчленения келловея. Тогда хлебновская свита может состоять из трех, докучаевская свита - из двух, малиновоовражная свита - из двух подсвит. При этом данные по фораминиферам [12] являются дополнительным свидетельством для такого деления. Именно подобный подход используется при описании местных подразделений, выделенных на севере Доно-Медведицких дислокаций.

Фактологической основой послужили материалы, собранные при детальном описании керна скважин и послойном палеонтологическом опробовании, произведенных В.Ф. Салтыковым, с последующими определениями аммонитов, двустворок, гастропод, белемнитов (Е.А.Троицкой) и фораминифер (Г.Н.Старцевой). Скважины находятся на севере Доно-Медведицких дислокаций в Волгоградской области. Ранее здесь в Каменных оврагах (вблизи Жирновска) были обнаружены Macrocephalites macrocephalus (Schloth.) и Kepplerites (Gowericeras) gowerianus (Sow.) [1]. В других обнажениях на этой площади Г.Ф.Лунгерсгаузен [22] нашел некоторые аммониты, в том числе и Cadoceras elatmae (Nik.) без указания его точного стратиграфического положения, на основании чего он произвел расчленение келловея на подъярусы. В разных частях района (чаще на востоке) отмечалось присутствие последнего аммонита. Более многочисленны данные по фораминиферам (определения А.И.Сарычевой при изучении выборочного керна в структурных скважинах). Однако эти сведения явно недостаточны, а главное - они являются разрозненными. Комплексное использование данных из скважин с высоким выходом керна дает возможность получить информацию из непрерывных разрезов. Важно отметить, что в ряде отобранных образцов из керна удалось обнаружить совместное нахождение макро- и микрофауны. Расположение скважин показано на рис. 1. Все они находятся на внешних сторонах флексур и в них установлены нижняя и верхняя границы келловея. Выход керна составлял 70-90\%.

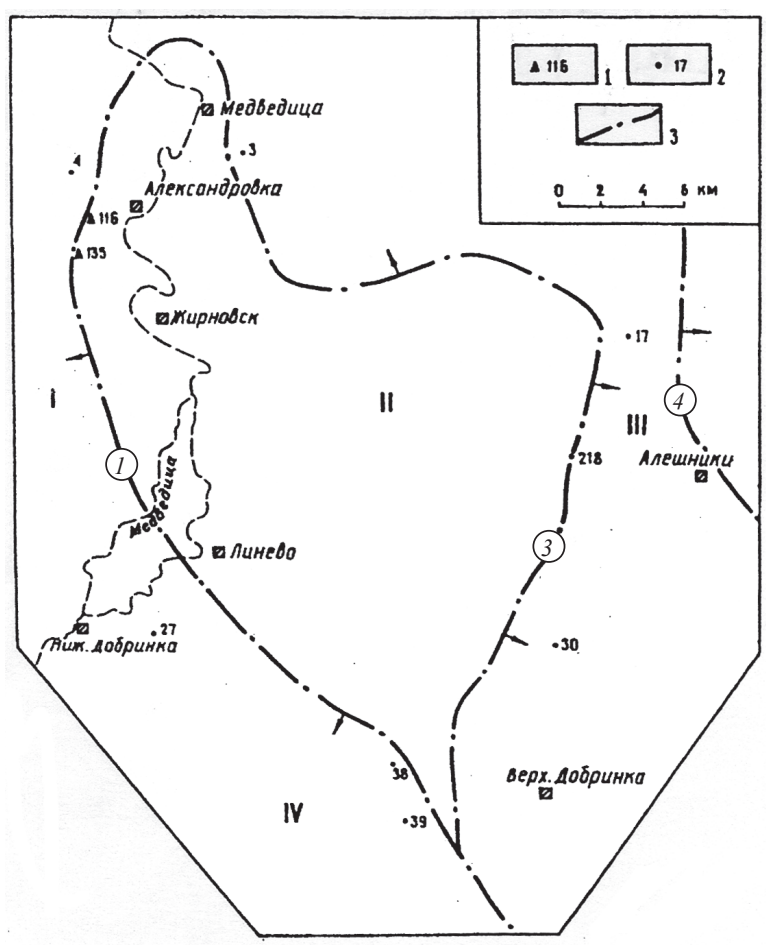

Рис. 1. Расположение скважин и обнажений на севере Доно-Медведицких дислокаций, вскрывших келловейские отложения: 1 - обнажения; 2 - скважины; 3 - флексуры в мезозое над разломами в палеозое; стрелками показано направление падения сместителя (цифры в кружках): 1 - Западно-Жирновская; 3 - Синегорская; 4 - Восточная; тектонические структуры: I - Терсинская впадина; II - Жирновско-Иловлинский вал; III - Приволжская моноклиналь; IV - Неткачевская седловина 
имели литология, включая и характер контактов между стратонами, и состав аммонитовых сообществ. При выделении подсвит определенную роль приобретали аммонитовые и фораминиферовые комплексы, установленные в отдельных диапазонах разреза, в соответствии с критериями Стратиграфического кодекса. Интервалы глубин для каждой подсвиты приводятся в табл. 1. местное подразделение комплексного обоснования при ее выделении [11], основное значение

\section{И ЛИТОЛОГИЧЕСКИЙ СОСТАВ СВИТ И ПОДСВИТ КЕЛЛОВЕЯ}

Корреляция разрезов в изученных скважинах

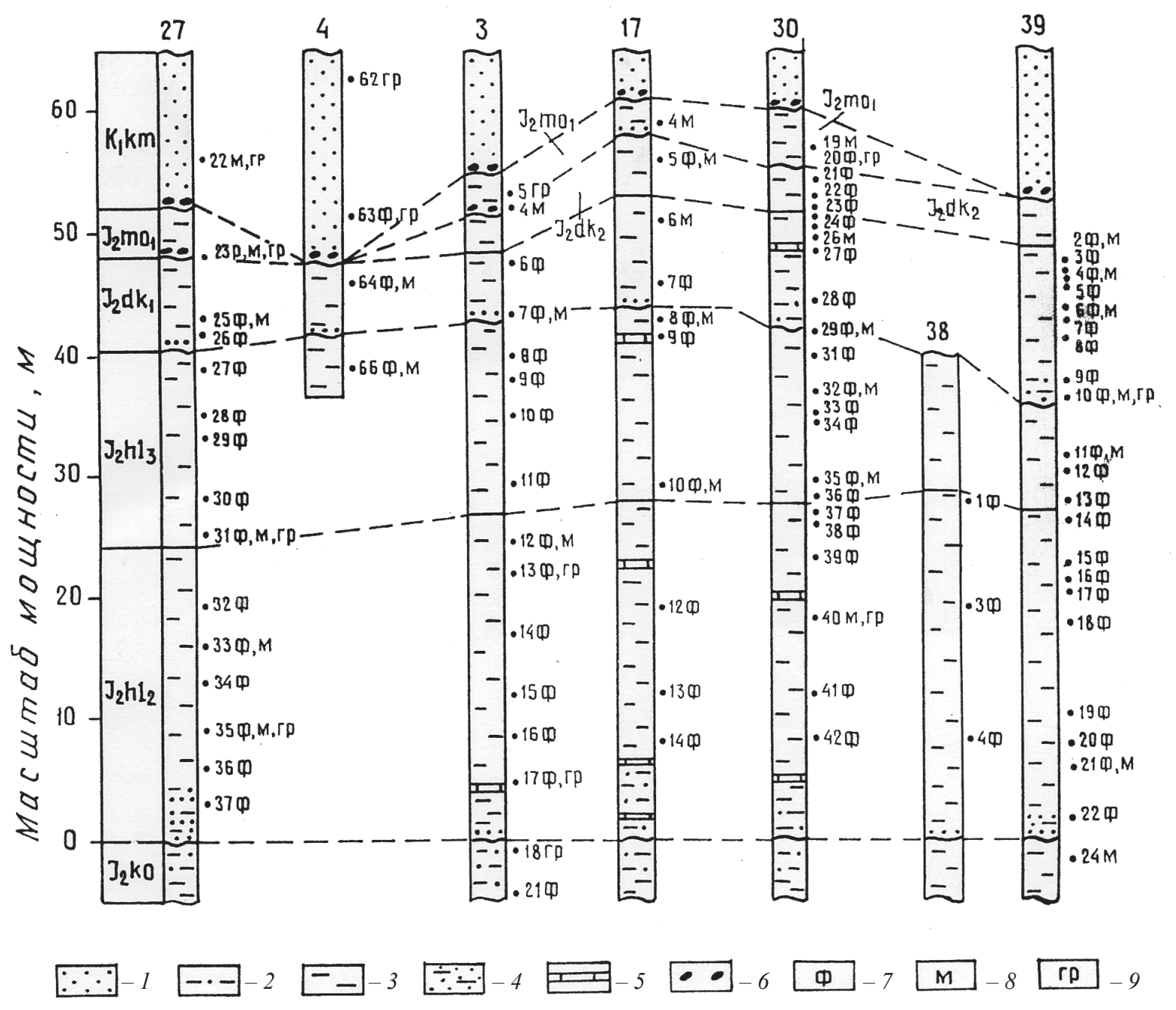

Рис. 2. Корреляция изученных подсвит в разрезе келловейских отложений по керну скважин на севере Доно-Медведицких дислокаций: 1 - пески; 2 - алевриты; 3 - глины; 4 - песчаные глины; 5 - известняки; 6 - стяжения фосфоритов; 7 - фауна; 8 - микрофауна; 9 - гранулометрия

Келловейские отложения везде залегают на алевритах и алевритовых глинах каменноовражной свиты $\mathrm{J}_{2}$ ко среднебатского возраста. В табл. 2 для сравнения дан один гранулометрический спектр пород кровли бата. В подошве келловея постоянно фиксируются различные количества песчаного или алевритового материала. В Малом Каменном овраге (обнажение 116) удалось наблюдать округлые скопления (или окатыши) светло-серых алевритов, похожих на каменноовражные породы, среди темно-серых келловейских глин. Учитывая отсутствие верхнего бата и отложений нижней зоны нижнего келловея (см. ниже), можно констатировать наличие перерыва осадконакопления в диапазоне верхний бат - низы келловея. Однако в базальных слоях не обнаружен галечник или крупнозернистый песок, что трактуется как указание на выровненный палеорельеф перед наступлением келловейского моря. 
Таблииа 1

Типовые разрезы келловейских отложений по керну скважин на севере Доно-Медведицких дислокаций

\begin{tabular}{|c|c|c|c|c|c|}
\hline \multirow{2}{*}{$\begin{array}{c}\text { Номера скважин (абсолют- } \\
\text { ные высоты устья, м) }\end{array}$} & \multicolumn{5}{|c|}{ Интервалы глубин, м, по подсвитам (мощность, м) } \\
\cline { 2 - 6 } & $\mathrm{J}_{2} \mathrm{hl}_{2}$ & $\mathrm{~J}_{2} \mathrm{hl}_{3}$ & $\mathrm{~J}_{2} \mathrm{dk}_{1}$ & $\mathrm{~J}_{2} \mathrm{dk}_{2}$ & $\mathrm{~J}_{2} \mathrm{mo}_{1}$ \\
\hline $3(261)$ & $89-62(27)$ & $62-46(16)$ & $46-41(5)$ & $41-37(4)$ & $37-34(3)$ \\
\hline $4(200)$ & - & $390-383(7)$ & $383-379(4)$ & - & - \\
\hline $17(279)$ & $94-65(29)$ & $65-50(15)$ & $50-41(9)$ & $41-35,5(5,5)$ & $35,5-33(2,5)$ \\
\hline $27(119)$ & $238-214(24)$ & $214-198(16)$ & $198-190(8)$ & - & $190-186(4)$ \\
\hline $30(284)$ & $167-140(27)$ & $140-125(15)$ & $125-116(9)$ & $116-112(4)$ & $112-107(5)$ \\
\hline $38(220)$ & $40-11(29)$ & $11-0(11)$ & & & \\
\hline $39(239)$ & $93,5-67(26,5)$ & $67-58(9)$ & $58-47(11)$ & $47-41(6)$ & - \\
\hline
\end{tabular}

Примечание. Расположение скважин показано на рис. 1, а корреляция литологического состава - на рис. 2.

Таблицьа 2

Гранулометрические спектры, \%, и минеральный состав глинистой фракции келловейских глин, подстилающих алевритов среднего бата и покрывающих песков верхнего готерива на севере Доно-Медведицких дислокаций

\begin{tabular}{|c|c|c|c|c|c|c|c|c|c|c|c|}
\hline \multirow{2}{*}{$\begin{array}{c}\text { Номера сква- } \\
\text { жин/ номера } \\
\text { образцов }\end{array}$} & \multirow{2}{*}{ Возраст } & \multicolumn{9}{|c|}{ Фракции, мм } & \multicolumn{4}{c|}{ Глинистые минералы, \% } \\
\cline { 3 - 15 } & $>1$ & $1-0,5$ & $0,5-0,25$ & $0,25-0,1$ & $0,1-0,01$ & $<0,01$ & гидрослюда & каолинит & хлорит & $\begin{array}{c}\text { смешано- } \\
\text { слойные }\end{array}$ \\
\hline $4 / 62$ & $\mathrm{~K}_{1} \mathrm{~km}$ & 0,4 & 26,9 & 1,1 & 48,5 & 13,8 & 9,3 & - & - & - & - \\
\hline $27 / 22$ & - & & 0,7 & 0,2 & 1,7 & 59,4 & 38,0 & 40 & 25 & 15 & 20 \\
\hline $4 / 63$ & - & & 0,2 & 0,2 & 1,7 & 72,6 & 25,3 & 35 & 20 & 15 & 30 \\
\hline $3 / 5$ & $\mathrm{~J}_{2} \mathrm{mo}_{1}$ & 0,1 & 0,1 & - & 0,2 & 6,5 & 93,1 & 60 & 15 & 10 & 15 \\
\hline $27 / 23$ & - & 0,2 & 0,5 & 0,1 & 1,2 & 7,8 & 90,2 & 60 & 20 & 10 & 10 \\
\hline $30 / 20$ & $\mathrm{~J}_{2} \mathrm{dk}_{2}$ & 0,2 & 1,3 & 0,2 & 2,4 & 20,7 & 75,2 & 40 & 40 & 10 & 10 \\
\hline $39 / 10$ & $\mathrm{~J}_{2} \mathrm{dk}_{1}$ & 0,1 & 0,1 & - & 0,3 & 14,6 & 84,9 & - & - & - & - \\
\hline $3 / 13$ & $\mathrm{~J}_{2} \mathrm{hl}_{2}$ & 0,1 & 0,5 & 0,2 & 0,9 & 6,3 & 92,0 & 35 & 5 & 20 & 40 \\
\hline $30 / 40$ & - & 1,1 & 2,6 & 0,4 & 3,2 & 11,2 & 81,5 & 40 & 20 & 10 & 30 \\
\hline Обн.135/2 & - & & 0,9 & - & 0,6 & 5,1 & 93,4 & - & - & - & - \\
\hline $27 / 35$ & - & 0,2 & 0,2 & - & 0,7 & 2,0 & 96,9 & 45 & 25 & 10 & 20 \\
\hline $3 / 17$ & - & 0,1 & 0,6 & - & 1,4 & 11,5 & 86,4 & - & - & - & - \\
\hline $3 / 18$ & $\mathrm{~J}_{2} \mathrm{ko}_{2}$ & 0,9 & 0,4 & - & 0,9 & 37,0 & 60,8 & 30 & 30 & 15 & 25 \\
\hline
\end{tabular}

Примечание. Расположение образцов по разрезу показано на рис. 2 (числитель - номер скважины, знаменатель - номер образца).

В изученных разрезах келловей представлен преимущественно алевритистыми глинами с плохо выраженной линзовидной слоистостью, содержащими небольшую примесь алевритовой составляющей (см. табл. 2). Среди них изредка наблюдаются линзовидные прослои алевритовых известняков темно-серого цвета с массивной текстурой. В отдельных прослоях, локализованных в низах среднехлебновской подсвиты свиты $\mathrm{J}_{2} \mathrm{hl}_{2}$, известняки частично сидеритизированы (до 20\%), но выше по разрезу примеси данного минерала в них не фиксируются. В этом же стратоне участками отмечается карбонатность глин (до 5\%), которая в вышележащих подразделениях возрастает до $30 \%$.

Эта однородность литологического состава келловейских глин затрудняет их расчленение. Однако тщательное изучение керна показало, что породы приподошвенных участков выделенных свит обогащаются песчаным или алевритовым материалом, а в основании малиновоовражной свиты $\mathrm{J}_{2}$ то верхнего келловея (скв. 3) встречены мелкие стяжения фосфоритов. В частности, в верхней части хлебновской свиты отмечены обломки углефицированной древесины, а вблизи границы с докучаевской свитой среднего келловея в скв. 30 на глубине 126 м зафиксирована линза сажистого черного угля мощностью 5 см. Эти литологические особенности свидетельствуют о перерывах в осадконакоплении. Они хорошо согласуются с распределением фауны, что дает основание проводить границы между свитами и 
прослеживать их по площади путем сопоставления конкретных каротажных кривых с созданной эталонной каротажной диаграммой (рис. 3), хотя пики на ней и не являются достаточно выразительными. Но в основании среднехлебновской и нижнемалиновоовражной подсвит четко видны резкие пики электросопротивлений, соответствующие опесчаненным породам. Другим признаком, фиксируемым при смене свит по разрезу, является изменение окраски глин. Для обеих подсвит хлебновской свиты характерен преимущественный темно-серый цвет, и породы почти лишены карбонатной примеси. Для отложений докучаевской и малиновоовражной свит свойственна более светлая окраска, и в них постоянно наблюдается дисперсное карбонатное вещество в сильно меняющихся количествах. Но смена окрасок происходит постепенно (в интервале до 5 м мощности), в результате чего провести границу трудно. Между подсвитами никаких литологических различий не отмечено, и границы между ними проводятся условно в зависимости от состава фораминиферовых комплексов и смены зональных аммонитов.

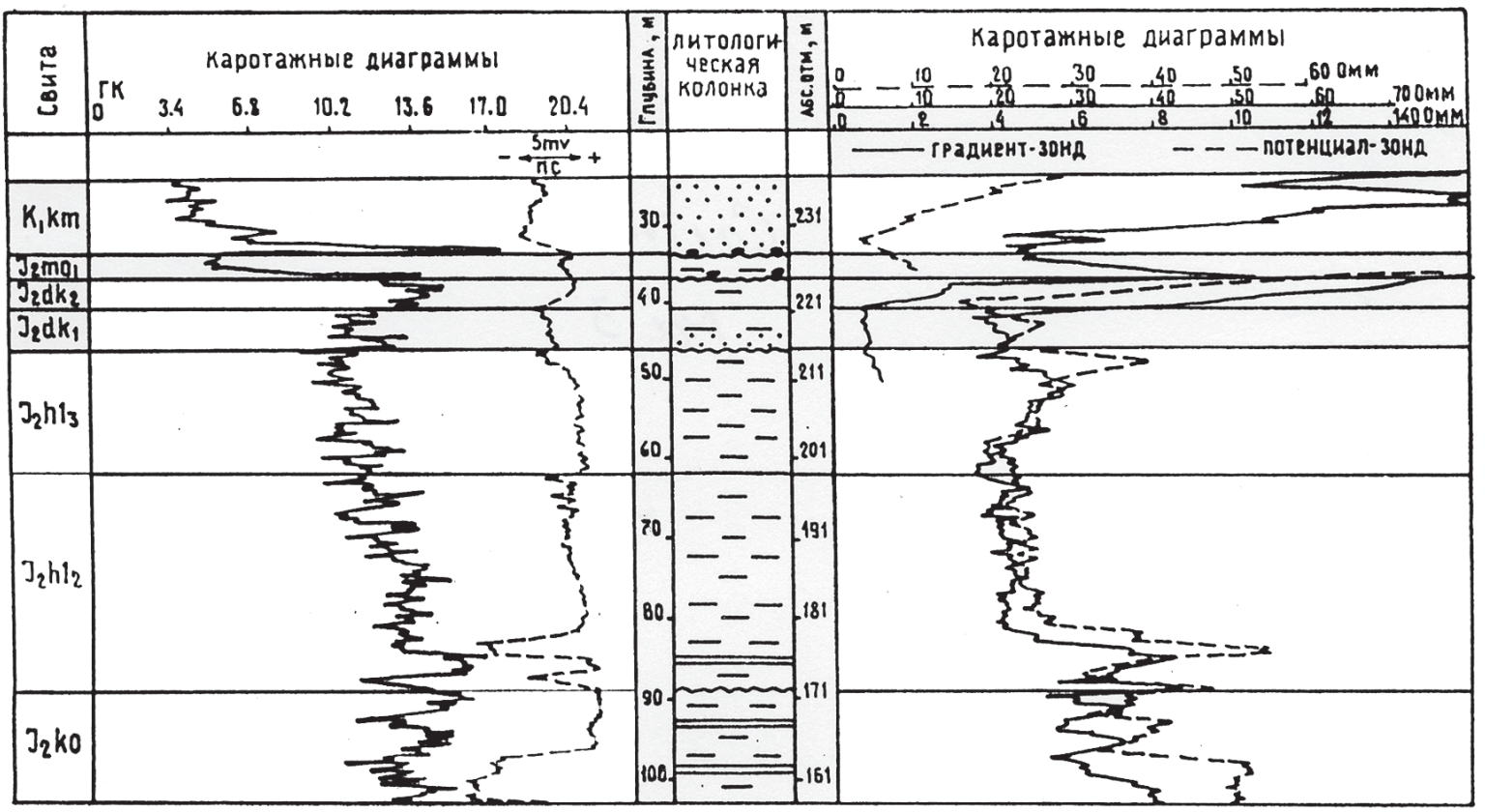

Рис. 3. Типовая каротажная диаграмма по скв. 3, вскрывшей две подсвиты хлебновской свиты $\left(\mathrm{J}_{2} \mathrm{hl} \mathrm{l}_{2}\right.$ и $\left.\mathrm{J}_{2} \mathrm{hl} \mathrm{l}_{3}\right)$, две подсвиты докучаевской свиты $\left(\mathrm{J}_{2} \mathrm{dk}_{1}\right.$ и $\left.\mathrm{J}_{2} \mathrm{dk}_{2}\right)$ и нижнюю подсвиту малиновоовражной свиты $\left(\mathrm{J}_{2}\right.$ mо $\left.{ }_{1}\right)$ : условные обозначения литологических разновидностей приведены на рис. 2

Количественные соотношения глинистых минералов в глинах келловея (см. табл. 2) меняются незначительно, и различия между подсвитами мало выразительны. Во всех породах доминируют гидрослюды и смешанослойные образования, содержание каолинита сильно варьирует, а хлорита - выровнено в пределах 10-20\%. В легкой фракции иммерсионных препаратов преобладает кварц, присутствуют и полевые шпаты, количество которых убывает вверх по разрезу в пределах каждой свиты. Тяжелая фракция в глинах хлебновской и докучаевской свит представлена циркон-рутил-ильменитовой ассоциацией, но в малиновоовражной свите она заменяется на циркон-гранат-хромитовую. Эти данные в той или иной мере подтверждают произведенное выделение свит, но указанные минералогические особенности не играют особой роли при разделении их на подсвиты. Кроме того, данные сведения свидетельствуют о незначительности перерыва между хлебнов- ской и докучаевской свитами. Однако граница между последней и малиновоовражной свитами, очевидно, приходится на более существенный временной промежуток отсутствия осадков, о чем свидетельствует и фосфоритовый горизонт между ними.

Для получения геохимической характеристики использованы данные спектрального анализа. Они обработаны с установлением корреляционных связей между изученными химическими элементами [23]. Такая методика дает возможность на полученных аддитивных графиках выделить границы между стратонами, представленные выразительными минимумами. В изучение вовлечены материалы из скв. 27, 38, 39. Результаты позволяют наметить две локальные устойчивые геохимические ассоциации, соответствующие хлебновской и докучаевской свитам, но между подсвитами границы не фиксируются. Таким образом, и геохимические сведения подтверждают произведенное расчленение. 
Верхняя граница келловея уверенно устанавливается, так как на среднеюрских глинах залегают различно окрашенные (от темно-серого до оранжево-желтого) глинистые мелко- (иногда средне-) зернистые пески климовской свиты $\mathrm{K}_{1} \mathrm{~km}$ позднеготеривского возраста. Их датировка обосновывается единичными находками аммонита Simbirskites sp. (скв. 4, образец 63) и фораминифер Cribrostomoides infracretaceus Mjatl. и Ammobaculites malodushenis Akim. (скв. 27, образец 22) (см. рис. 2). В базальном слое песков постоянно наблюдаются мелкие стяжения фосфоритов. Контакт между келловеем и готеривом носит ярко выраженный размывной характер и является неровным. В результате чего в разных скважинах сохраняются неодинаковые части келловея (см. рис. 2). Только в скв. 3, 17, 27, 30 наблюдается нижнемалиновоовражная подсвита, в скв. 3, 17, 30, 39 присутствует верхнедокучаевская подсвита, а в скв. 4 установлены лишь верхи нижней подсвиты $\mathrm{J}_{2} \mathrm{dk}_{1}$. Однако полный объем данного стратона, как и хлебновской свиты, наблюдается во всех остальных скважинах.

Эти обстоятельства обусловливают вариации мощностей выделенных подсвит: для среднехлебновской подсвиты $\mathrm{J}_{2} \mathrm{hl}_{2}$ они находятся в пределах 24-29 м; для верхней подсвиты $\mathrm{J}_{2} \mathrm{hl}_{3}-9-16$ м; для нижнедокучаевской подсвиты $\mathrm{J}_{2} \mathrm{dk}_{1}-5-11$ м; для верхней подсвиты $\mathrm{J}_{2} \mathrm{dk}_{2}-4-6 \mathrm{~m}$; для нижнемалиновоовражной подсвиты $\mathrm{J}_{2} \mathrm{mo}_{1}-3-5$ м. Если мощности подсвиты $\mathrm{J}_{2} \mathrm{hl}_{2}$ изменяются вокруг величины 25 м, то вариации мощностей верхней подсвиты $\mathrm{J}_{2} \mathrm{hl}_{3}$ становятся значительными, отражая различную степень размыва отложений. Эта картина является наиболее впечатляющей для обеих подсвит докучаевской свиты.

Общая мощность келловея на изученной территории составляет 53-61 м. При этом она увеличивается в юго-восточном направлении (уже в пределах Приволжской моноклинали) до 80 м (по данным структурных скважин) или даже до 110 м [24], очевидно, за счет возрастания мощностей подразделений среднего и верхнего келловея. Рассмотренные закономерности изменения мощностей свидетельствуют о достаточной сложности размещения различных свит келловея по площади, обусловленной разной степенью размыва отложений.

\section{Палеонтологическая характеристика келловейских отложений}

Исследованные келловейские отложения богаты различными органическими остатками. По сравнению с изученным в тех же самых скважинах нижним батом встречаемость фауны возрастает почти вдвое, а при сопоставлении со средним батом, очень бедным фауной, количество органических остатков увеличивается почти десятикратно. При этом на границе бат - келловей происходит практически полное обновление фауны и существенно возрастает видовое разнообразие.

Частота встречаемости и степень видового разнообразия отмечаются и при переходе от одной свиты келловея к другой. Распределение образцов с фаунистическими остатками по каждой скважине демонстрируется на рис. 2. Однако эти данные не являются наглядными, в связи с чем распределение видов аммонитов (рис. 4) и фораминифер (рис. 5, см. вкл.) дано в суммированной форме. Ввиду вариаций мощностей подразделений применен сводный разрез, на котором образцы с фауной располагались в зависимости от расстояния от подошвы стратона. Усреднение мощностей приводит к тому, что точность положения образца варьирует в пределах 1-2 м по сравнению с конкретным разрезом. Но эта точность вполне достаточна для обоснования возраста стратона, границы которого проводятся отдельно в каждом разрезе по комплексу признаков (см. рис. 2).

Распределение аммонитов. Всего обнаружено 16 видов аммонитов и произведено 3 родовых определения в 80 образцах (см. рис. 4). В 15 из них одновременно было установлено присутствие двух видов. При этом часто отмечаются сочетания Macrocephalites macrocephalus (Schloth.) и Chamoussetia chamousseti (Orb.), последнего с Kepplerites (Gowericeras) gowerianus (Sow.), различные виды родов Kosmoceras и Hecticoceras.

В некоторых образцах определено до 3 экземпляров одного и того же вида аммонитов. Это наиболее свойственно для $M$. macrocephalus (Schloth.), Ch. chamousseti (Orb.) и K. (G.) gowerianus (Sow.), установленных в хлебновской свите. Первые два вида чаще встречаются в средней подсвите, и количество экземпляров существенно убывает в верхней. Наоборот, третий вид наиболее обилен в верхней подсвите, и его встречаемость возрастает почти вдвое по сравнению со средней. Широкое вертикальное распространение данных видов в нижнем келловее неоднократно упоминалось в литературе [1]. Представленная статистика в какой-то мере уточняет подобные соображения. Ocобенно это касается Ch. chamousseti (Orb.), для которого Дж. Калломон и Дж. Райт [14] отмечали большую встречаемость совместно с $M$. macrocephalus (Schloth.), приуроченных к зоне koenigi.

Следует отметить, что хотя $K$. $(G$.$) gowe-$ rianus (Sow.) характерен исключительно для нижнего келловея, в единичных экземплярах в некоторых образцах он встречен в низах докучаевской свиты среднего келловея. Данный факт следует трактовать скорее как свидетельство переотложения аммонитов, так как в этих же образцах установлен фораминиферовый комплекс Lenticulina pseudocrassa - L. cultratiformis, который свойствен нижнедокучаевской подсвите. В одном образце (3/9) определен Kosmoceras sp. в верхах верхнехлебновской подсвиты (зона calloviense), хотя указанный род характерен для среднего и отчасти верхнего подъярусов. 


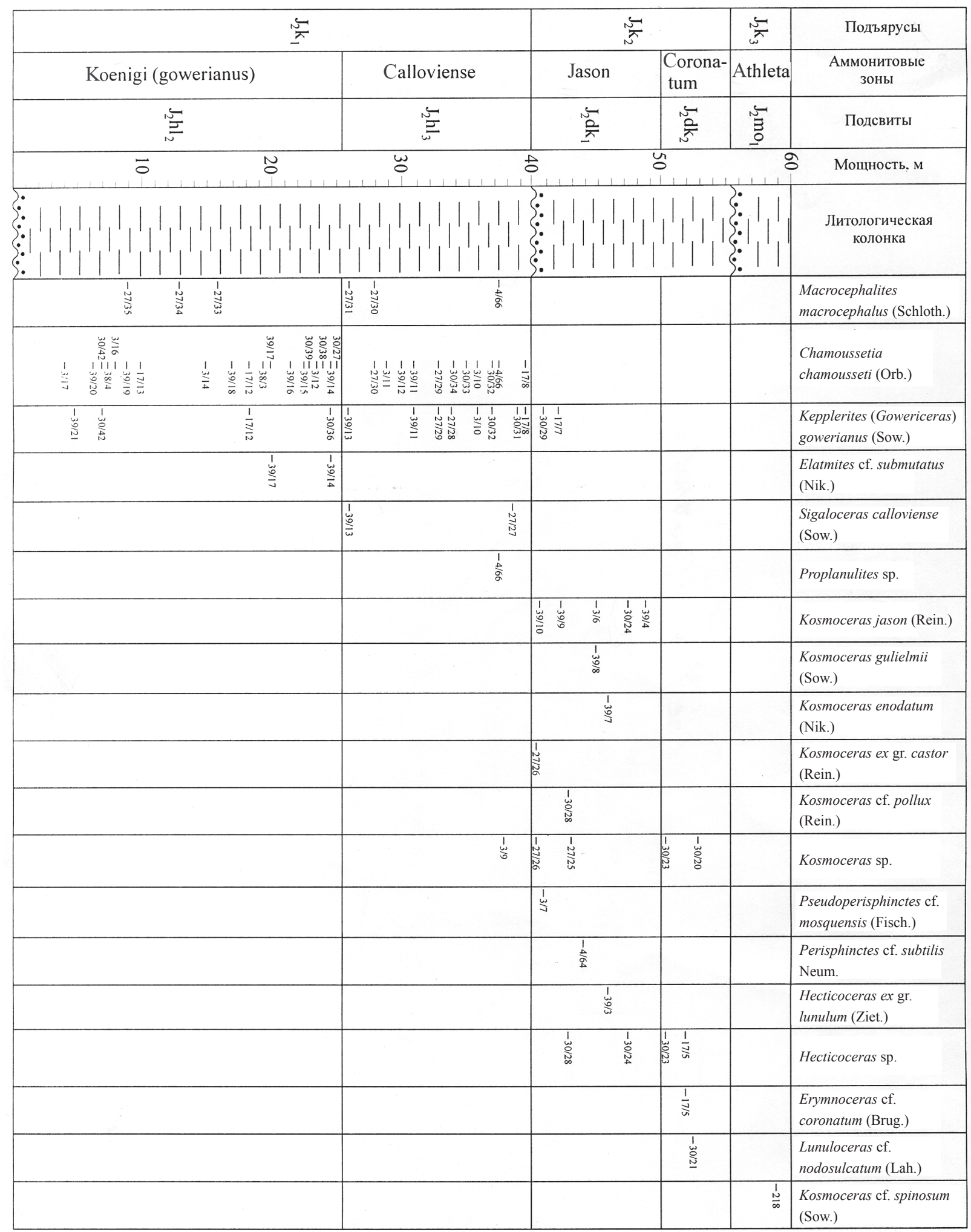

Рис. 4. Распределение видов аммонитов по усредненному разрезу келловейских отложений на севере Доно-Медведицких дислокаций: символы литологических разновидностей приведены на рис. 2; цифры обозначают номера скважин (числитель) и образцов (знаменатель) 
Возможно, что он относится к виду Sigaloceras enodatum (Nik.), который встречается в терминальных слоях нижнего келловея.

За исключением перечисленных особенностей данные рис. 4 свидетельствуют о достаточно надежной возрастной датировке свит. Кроме того, намечается определенная корреляция аммонитовых зон с предложенными подсвитами. Для всей хлебновской свиты свойственны M. macrocephalus (Schloth.), Ch. chamousseti (Orb.), K. (G.) gowerianus (Sow.). Но в средней подсвите добавляется Elatmites cf. submutatus (Nik.). Возможно, его следует рассматривать в составе рода Indosphinctes. В верхней подсвите из двух образцов, расположенных в подошве и кровле стратона, но в разных скважинах, определены зональные аммониты Sigaloceras calloviense (Sow.).

Аммонитов, характерных для нижней зоны подъяруса (herveyi), в изученных разрезах не обнаружено, хотя на востоке района ранее были встречены отпечатки Cadoceras elatmae (Nik.), но их стратиграфическое положение не является точно установленным. Можно предполагать, что нижние 5 м в данных разрезах следовало бы относить к зоне herveyi, но отобранные образцы не содержат остатков ни аммонитов, ни фораминифер. С.В.Меледина полагала, что «...достоверных выходов зоны в более южных районах европейской части СССР (южнее Саратова. - B.C.) не известно ... отдельные находки Macrocephalites и Cadoceras на площади Нижней Волги не могут считаться основанием для установления нижней половины нижнекелловейского подъяруса» [25, с. 122]. Кроме того, вид C. elatmae (Nik.) может по вертикали проникать и в зону koenigi, что отмечала С.В.Меледина для разреза в Малиновом овраге [5]. Аналогично высказывалась В.Г.Камышева-Елпатьевская [1]. Поэтому можно достаточно уверенно предполагать, что на севере Доно-Медведицких дислокаций нижний келловей представлен в основном двумя верхними зонами - koenigi и calloviense, которым соответствуют средняя и верхняя подсвиты хлебновской свиты. Но в последней, вероятно, отсутствуют отложения, приходящиеся на верхний биогоризонт $S$. enodatum [16-18].

Этим наши материалы отличаются от сведений по разрезу в Малиновом овраге, где обнаружены виды C. elatmae (Nik.), Costacadoceras mundum (Sas.) и $M .(M$.$) cf. triangularis Spath в$ породах мощностью более 10 м [6], перекрытых отложениями, содержащими вышеуказанные виды в изученных нами разрезах. Это позволило Ю.С.Репину и Н.Х.Рашвану [6] предполагать существование в Малиновом овраге части нижней аммонитовой зоны herveyi. Нахождение в Елшанском разрезе (к югу от Малинового оврага) аммонитов C. cf. bodylevskii Freb. и Kepplerites cf. keppleri (Opp.) [21] подтверждает данное предположение. В пользу этого свидетельствует встречаемость фораминиферы Reophax scabrosus Starts. в породах из Малинового оврага [12], которую Г.Н.Старцева [26] относила к самым низам келловея, вероятно, к зоне herveyi. В то же время следует заметить, что Дж. Калломон и Дж. Райт [14] полагали, что описанная В.Г.Камышевой-Елпатьевской и др. [1] коллекция аммонитов из Малинового оврага больше подходит к зоне koenigi, о чем свидетельствует частота встречаемости вида $K$. $(G$. gowerianus (Sow.), тем более что вид C. elatmae (Nik.) в Западной Европе не известен. Ранее в работе [27] данный вид соотносился с зоной koenigi стандарта. Вероятно, вертикальное распространение этого вида является более широким, на что обращали внимание некоторые исследователи.

В докучаевской свите исчезают все виды аммонитов, установленных в хлебновской свите. Для нижней подсвиты характерно видовое разнообразие представителей рода Kosmoceras: часто встречается зональный вид K. jason (Rein.), более редки другие представители - K. gulielmii (Sow.), $K$. enodatum (Nik.), $K$. ex gr. castor (Rein.), $K$. cf. pollux (Rein.), отмечаются Pseudoperisphinctes cf. mosquensis (Fish.), Perisphinctes cf. subtilis Neum., Hecticoceras lunulum (Ziet.). Однако необнаружение вида-индекса $K$. medea (Call.) свидетельствует, видимо, об отсутствии отложений самого нижнего биогоризонта среднего келловея.

Верхняя подсвита $\mathrm{J}_{2} \mathrm{dk}_{2}$ относительно бедна остатками аммонитов. Но присутствие зонального вида Erynmoceras coronatum (Brug.) и вида Lunuloceras nodosulcatum (Lah.), отобранных выше нижней подсвиты (зоны jason), однозначно свидетельствует об ее самостоятельности. Эти данные не согласуются с утверждением о совместном нахождении видов K. jason (Rein.) и E. coronatum (Brug.) в отложениях среднего келловея в других районах Русской платформы $[8,9]$. Такое мнение противоречит давно установленному факту их раздельного размещения в отложениях Поволжья $[1,2]$. То же отмечает для центральных районов Д.Н.Киселев [20]. Аналогичное явление получило свое отражение в зональном стандарте суббореального келловея [15]. Этот момент особо важен для более надежного определения стратиграфической позиции фораминиферового комплекса из верхнедокучаевской подсвиты. Однако верхняя подзона grossouvrei, очевидно, не представлена в изученных разрезах. Можно предполагать ее размыв в позднекелловейское время.

К сожалению, в изученной нами части малиновоовражной свиты остатков аммонитов не встречено. Возраст этих отложений обоснован фораминиферовыми сообществами. Однако в скважине ручного бурения 218 (А.Ф.Кучаев, 1965) был найден аммонит Kosmoceras cf. spinosum (Sow.) совместно с фораминиферой Ammobaculites aff. latus Mitjan., характерных для верхов зоны athleta - нижней зоны верхнего келловея. Скважина 218 находится на расстоянии 6,5 км к югу от нашей скв. 17 вдоль Синегорской флексуры. По гипсометрическому положению находка этого 
аммонита соответствует верхам разреза в скв. 17, где также были обнаружены фораминиферы, свойственные для верхнего подъяруса.

Таким образом, по аммонитам можно уверенно выделять свиты в келловее, особенно с привлечением литологических признаков, в том числе и особенностей контактов между ними. Тем не менее на уровне подсвит возникают трудности, обусловленные отсутствием иногда зональных видов. Поэтому в единичных обнажениях и скважинах такое расчленение не всегда успешно реализуется. Так же трудно обеспечить проведение границ подсвит, но подобная процедура становится надежной при использовании данных по фораминиферам.

Распределение двустворок, гастропод и белемнитов. В изученных разрезах зачастую совместно с аммонитами были обнаружены представители других моллюсков. По сравнению с батом в келловее эта фауна почти полностью обновляется - встречаются лишь отдельные общие для обоих ярусов раковины двустворок и гастропод. Систематический состав изученной фауны сходен с таковым в работе [2]. Попытки выявить характерные сообщества в каждом выделенном стратоне не увенчались успехом, в связи с чем приводятся только некоторые особенности их распределения по разрезу келловейских отложений.

1. Наиболее часто встречаются двустворки (21 род и 36 видов) и гастроподы (по 20 родов и видов). Из них особо обильны бивальвии Posidonia buchi (Roem.), Parallelodon pictum (Mil.), Camptonectes lens (Sow.), представители родов Entolium и Corbula, а также гастроподы Procerithium russiense (Orb.), Cryptaulax echinata (Buch), Cr. pseudoechinata Ger. и лопатоногие моллюски рода Dentalium. Особо следует подчеркнуть диагностическую роль гастропод, характерных именно для келловея.

2. Максимумы встречаемости многих видов приходятся на верхнехлебновскую подсвиту $\mathrm{J}_{2} \mathrm{hl}_{3}$ и в меньшей степени на нижнедокучаевскую подсвиту $\mathrm{J}_{2} \mathrm{dk}_{1}$. Причем снизу вверх по разрезу отмечается убывание разнообразия двустворок и гастропод с уменьшением количественной встречаемости, когда некоторые виды вообще исчезают.

Таким образом, выявленные особенности распределения двустворок и гастропод свидетельствуют о родственных связях между выделенными свитами, несмотря на отмеченные признаки перерывов в осадконакоплении. Вероятно, они были кратковременными и, возможно, скорее указывали на обмеление бассейна седиментации, чем на собственно перерывы.

Фораминиферовые комплексы являются наиболее информативными и чувствительными индикаторами, применяемыми при расчленении келловейских отложений. В существующих стратиграфических схемах [28] фораминиферовые зоны сопоставляются по объему с подъярусами, хотя последние по аммонитам делятся на более дробные единицы (зоны и подзоны). Выполненное опробование в скважинах позволило связать аммонитовую и фораминиферовую зональности в изученных почти непрерывных разрезах келловея, обосновать выделение подсвит и провести их границы с точностью порядка первых метров.

Представленные материалы (см. рис. 5) свидетельствуют, что для отложений аммонитовой зоны koenigi (подсвита $\mathrm{J}_{2} \mathrm{hl}_{2}$ ) характерен комплекс Haplophragmoides infracalloviensis - Guttulina tatariensis, в которых также важную роль играют виды Ammobaculites fontinensis (Terq.), Recurvoides ventosus (Chab.), Marginulina mjatliukae Shokh., $M$. krylovae Mjatl., Dentalina vasta Mjatl., Gaudryina sp., что отмечалось многими исследователями. Почти все они относятся к агглютинирующим формам. Большинство из них не встречаются в вышележащей подсвите. Одновременно здесь появляются первые Lenticulina tatariensis (Mjatl.) и L. praerussiensis Mjatl., более свойственные верхнехлебновской подсвите $\mathrm{J}_{2} \mathrm{hl}_{3}$. Наши данные не согласуются с ранним представлением [28], что этот комплекс соответствует всему объему нижнего подъяруса.

Для верхнехлебновской подсвиты $\mathrm{J}_{2} \mathrm{hl}_{3}$, сопоставляемой с аммонитовой зоной calloviense, характерен комплекс L. tatariensis - Epistomina callovica, в котором доминируют представители родов Lenticulina, Epistomina, Pseudolamarckina, Astacolus, причем многие виды локализуются только в пределах этой подсвиты, хотя сравнительно редкие из них переходят и в вышележащие отложения (см. рис. 5). Большинство данных таксонов принадлежат к секреционным формам. Эти сведения подчеркивают целесообразность выделения указанного сообщества в самостоятельный фораминиферовый комплекс, что отмечалось ранее в работах $[26,29]$.

В нижнедокучаевской подсвите, соответствующей аммонитовой зоне јason среднего келловея, наблюдается комплекс L. pseudocrassa-L. cultratiformis с характерными видами L. cidaris Kosyr., L. praepolonica K.Kuzn., Ep. mosquensis Uglig, Ep. ukrainica Kapt., Pseudolamarckina orbiculata Starts. (виды-индексы выделены полужирным шрифтом). Здесь вообще отмечается видовое разнообразие фораминифер, особенно среди сопутствующих форм, из которых часто встречаются Astacolus nobilis (Kapt.), As. calloviensis (Mjatl.), Planularia flexuosa (Bruck.), Saracenaria gracilis Kosyr., Ep. porcillanea Bruck. Здесь же впервые появляются L. elschankaensis Mjatl., более обильные в верхнем келловее [12, 26, 30].

Для верхнедокучаевской подсвиты $\mathrm{J}_{2} \mathrm{dk}_{2}$ (зона coronatum) свойственно существенное обеднение систематического состава фораминифер. Встречаются виды L. cidaris Kosyr., Saracenaria gracilis Kosyr. и Ep. mosquensis Uhlig, характерные для среднего келловея [31]. Впервые появляются представители L. tumida Mjatl. и L. polonica (Wisn.), более свойственные верхнему келловею. Эта бедность 
систематического состава сообщества и обусловила, очевидно, его объединение с комплексом из подсвиты $\mathrm{J}_{2} \mathrm{dk}_{1}$, что отражено во многих публикациях [12, 28-30, 32]. Но именно указанный признак наряду с совместной встречаемостью средне- и верхнекелловейских форм подчеркивает необходимость выделения самостоятельного комплекса, отражающего смену фораминиферовых сообществ на границе докучаевской и малиновоовражной свит.

Наконец, в нижнемалиновоовражной подсвите $\mathrm{J}_{2} \mathrm{mo}_{1}$ часто наблюдаются Ep. rjasanensis (Uman. et Zw.), Ep. elschankaensis Mjatl., Lenticulina tumida Mjatl., L. polonica (Wisn.), Planularia colligata (Bruck.), Ichtyolaria supracalloviensis (Wisn.). Сюда переходят некоторые виды из докучаевской свиты $\mathrm{J}_{2} \mathrm{dk}$, но отсутствует вид L. cidaris Kosyr. Кроме того, в базальных слоях установлены фораминиферы Haplophragmoides sp., Ammobaculites quadrifidus Mitjan. и Trochammina fibriata E. Byk. et Jak., живущие на песчанистых субстратах. Многие исследователи относят их к позднему келловею. К сожалению, изученная незначительная часть разреза не позволяет выявить полный систематический состав комплекса.

Рассмотренный состав изученных фораминиферовых сообществ практически полностью, за редким исключением (особенно в нижнем келловее, где часто дополнительно отмечаются Ammobaculites coprolithiformis Schwag., Astacolus hybrida (Terq.), Dentalina macrocephali (Kubl. et Zw.)), совпадает с данными многих публикаций по стратиграфии келловея Русской платформы [12, 26, 28-30, 32]. Соотношение с аммонитами выявляет четкую связь фораминиферовых комплексов с аммонитовой зональностью. Сведения рис. 5 показывают достаточно резкую сменяемость ассоциаций микрофауны в разрезе, обусловливая дробное деление келловейских отложений Поволжья по сравнению с существующей схемой $[28,32]$. Очевидно, что точная привязка образцов в непрерывных разрезах в других районах Русской платформы, датированных аммонитами, сможет подтвердить правомерность выделения предложенных фораминиферовых комплексов и обоснованность их корреляции с аммонитовыми зонами.

\section{Заключение}

Суммируя изложенные сведения, можно сделать некоторые заключительные замечания.

1. Представленные данные подтверждают в рассматриваемом районе Поволжья относительно стратотипа в Малиновом овраге выделенные свиты, соответствующие по объему подъярусам. Литологические признаки и вариации мощностей свидетельствуют о самостоятельности свит в келловее. Однако более тщательно проведенные палеонтологические исследования выявляют возможность выделения подсвит в каждой свите, причем они соответствуют аммонитовым зонам и характеризуются собственными фораминиферо- выми комплексами, т. е. для изученных отложений происходит сопряжение аммонитовой и фораминиферовой зональностей в пределах келловея. Важно отметить, что в основании каждой свиты преобладающие глины опесчаниваются, а в подошве малиновоовражной свиты наблюдаются желваки фосфоритов. Внутри этих стратонов границы между подсвитами проводятся исключительно по палеонтологическим данным.

2. Материалы по скважинам дают основание оценить палеонтологические находки а Каменных оврагах вблизи Жирновска (обнажения 116 и 135), где были обнаружены M. macrocephalus (Schloth.) и $K .(G$.) gowerianus (Sow.) [1]. В разрезе, где был найден $K$. (G.) gowerianus (Sow.), были обнаружены и фораминиферы Ammobaculites quadrifidus Mitjan. Учитывая расположение отложений в зоне флексуры, где они залегают под крутыми углами, в результате чего отсутствует непрерывный разрез, можно полагать, что в оврагах вскрываются части нижнего келловея (видимо, зоны koenigi) и фрагменты верхнего келловея.

3. Несмотря на обнаружение аммонита $C$. elatmae (Nik.) в нижнем келловее, указанное в ряде геолого-съемочных отчетов, его точное геологическое положение остается неопределенным. В наших образцах этот аммонит, как и комплекс фораминифер, характерных для зоны herveyi нижнего келловея [12], не установлен. Поэтому самый древний стратон отнесен к средней подсвите хлебновской свиты $\mathrm{J}_{2} \mathrm{hl}_{2}$, соответствующей аммонитовой зоне koenigi. Нижняя зона herveyi, к которой многие исследователи относят аммонит C. elatmae (Nik.), видимо, в изученных скважинах отсутствует, хотя нельзя исключить, что самые нижние 5 м отложений без фаунистического обеспечения могут принадлежать верхам этой зоны.

4. Полные разрезы келловея выявлены в скв. $3,17,30$, расположенных на востоке района (на краю Приволжской моноклинали). На западе в скважинах повсеместно присутствует хлебновская свита и изредка фиксируется часть нижнедокучаевской подсвиты. Изменение величин мощностей в скважинах свидетельствует о различной степени сохранности разреза на разных участках обследованной площади. Очевидно, это обусловлено как приуроченностью к определенной тектонической структуре, так и условиями седиментации в течение века, что возможно выявить при анализе карт изопахит.

5. Некоторая обедненность находок аммонитов в керне изученных скважин тем не менее не помешала выделению аммонитовых зон. Достаточно полные фораминиферовые комплексы вообще не сравнимы с описанными из разреза в Малиновом овраге. Поэтому целесообразно разрезы в данных скважинах рассматривать в качестве дополнительного стратотипа (гипостратотипа) келловейских свит, тем более что здесь обосновывается выделение подсвит и возможна более детальная фораминиферовая зональность яруса. 
В заключение автор выражает свою благодарность А.Ю.Гужикову, Е.М.Первушову, В.Б.Сельцеру и Г.Н.Стариеевой за консультациии и сделанные критические замечания.

\section{Библиографический список}

1. Камышева-Елпатьевская В.Г., Николаева В.П., Троицкая E.A. Стратиграфия юрских отложений Саратовского Правобережья по аммонитам // Тр. ВНИГРИ. 1959. Вып. 137. С. 3-265.

2. Николаева В.П., Троицкая Е.А. Фаунистическая характеристика келловея Саратовского и Волгоградского Поволжья // Вопр. стратиграфии и палеонтологии. Саратов, 1975. Вып. 1. С. 42-54.

3. Алексеев С.Н., Репин Ю.С. Новые данные по келловейским отложениям Малинового оврага (Саратовское Поволжье) // Юрские отложения Русской платформы. Л., 1986. C. $130-137$.

4. Кулева Г.В., Троиикая Е.А., Букина Т.Ф. и др. Опорный разрез келловейского яруса оврага Малиновый. Саратов, 1988. 55 с. Деп. ВИНИТИ 10.06.88, № 4605-B88.

5. Меледина С.В. Аммониты и зональная стратиграфия келловея суббореальных районов СССР // Тр. ИГГ АН СССР. 1987. Вып. 691. 184 с.

6. Репин Ю.С., Рашван Н.Х. Келловейские аммониты Саратовского Поволжья и Мангышлака. СПб., 1996. 256 с.

7. Левина В.И., Прохорова Н.П. Местные стратиграфические подразделения нижней и средней юры Прикаспийского региона // Недра Поволжья и Прикаспия. 2002. Вып. 29. C. 6-13.

8. Олферьев А.Г. Юрские отложения востока Русской платформы // Вопр. совершенствования стратиграфической основы фанерозойских отложений нефтегазоносных регионов России. СПб., 1997. С. 95-107.

9. Объяснительная записка к унифицированной стратиграфической схеме юрских отложений Русской платформы. СПб., 1993. $72 \mathrm{c.}$

10. Салтыков В.Ф., Сельцер В.Б. Анализ изученности опорных разрезов келловея в Поволжье // Изв. Сарат. унта. Нов. сер. Науки о Земле. 2005. Т. 5, № 1/2.

11. Стратиграфический кодекс. 2-е изд. / Ред. А.И.Жамойда. СПб., $1992.120 \mathrm{c}$.

12. Стариева Г.Н., Хабарова Т.Н. Ульяновско-Саратовский прогиб и северо-западная часть Прикаспийской впадины // Биостратиграфия верхнеюрских отложений СССР по фораминиферам / Под ред А.А. Григялиса. Вильнюс, 1982. C. $50-61$.

13. Callomon J.Y., Dietl G., Niederhofer H.J. On the true stratigraphic position of Macrocephalites macrocephalus (Schlotheim, 1813) and the nomenclature of the standard Mittle Jurassic «Macro-cephalus Zone» // Stuttg. Beitr. Naturk. 1992. Ser. B. № 185.65 p.

14. Callomon J.H., Wright J.K. Cardioceratid and Kosmoceratid ammonites from the Callovian of Yorkshire // Palaeontology. 1989. V. 32. P. 799-836.

15. Thierry J., Cariou E., Elmi S. et al. Callovian// Bul. Centre Rech. ELF Explor. 1997. Mem. 17. P. 63-78.

16. Мumma В.В. Аммониты рода Macrocephalites в кел- ловее Центральной России // Новости из Геол. музея им. В.И. Вернадского. 1998. № $1.11 \mathrm{c}$.

17. Митта B.B. Аммониты и биостратиграфия нижнего келловея Русской платформы // Бюл. КФ ВНИГНИ. 2000. № $3.144 \mathrm{c}$.

18. Митта B.B. О проблемах биостратиграфии средней юры Европейской России // Недра Поволжья и Прикаспия. 2004. Вып. 39. С. 28-33.

19. Gulyaev D.B., Kiselev D.N., Rogov M.A. Biostratigraphy of the Upper boreal Bathonian and Callovian of European Russia // VI Inter. Symp. of the Jurassic System. Palermo, 2002. P. 81-82.

20. Киселев Д.Н. Зоны, подзоны и биогоризонты среднего келловея Центральной России // Тр. естественно-географ. фак. Яросл. гос. пед. ун-та им. К.Д.Ушинского. 2001. Спец. вып. $1.38 \mathrm{c}$.

21. Сельцер В.Б. Нижняя граница келловейского яруса на территории Нижнего Поволжья // Проблемы геологии Европейской России: Тез. докл. Всерос. науч.-практ. конф., 29-31 октября 2002 г. Саратов, 2002. С. 45-46.

22. Лунгерсгаузен Г.Ф. Материалы по стратиграфии мезозойских и палеогеновых отложений северной ветви Доно-Медведицких дислокаций // Тр. Всесоюз. аэрогеол. треста. 1956. Вып. 2. С. 190-255.

23. Пименов М.В., Гужиков А.Ю., Салтыков В.Ф. Выделение реперных корреляционных уровней по геохимическим данным для стратификации среднеюрских отложений на севере Доно-Медведицких дислокаций // Юрская система России: проблемы стратиграфии и палеогеографии. Материалы Первого Всерос. сов. М., 2005. С. 193-194.

24. Смирнов А.В. Литология и литофация юрских отложений Волгоградского Поволжья // Тр. Волгогр. НИИНГ. 1962. Вып. 1. С. 111-129.

25. Меледина C.В. Зональное деление келловея Русской платформы // Юрские отложения Русской платформы. Л., 1986. C. $119-129$.

26. Стариева Г.Н. Детальное расчленение верхнеюрских отложений Среднего Поволжья по данным изучения фораминифер // Юрские отложения Русской платформы. Л., 1986. С. 30-40.

27. Зоны юрской системы в СССР / Ред. Г.Я.Крымгольц // Тр. МСК. 1982. Т. 10. 192 с.

28. Григялис А.А., Кузнечова К.И. Стратиграфическая шкала верхней юры СССР по фораминиферам // Изв. АН СССР. Сер. геол. 1987. № 5. С. 26-37.

29. Пяткова Д.М. Корреляция верхнеюрских отложений платформенной части Украины с одновозрастными образованиями южных районов СССР по фораминиферам // Стратиграфия и корреляция верхней юры СССР по фораминиферам. М., 1985. С. 91-96.

30. Хабарова Т.Н. О микрофауне юрских отложений Саратовской области // Тр. ВНИГНИ, 1961. Вып. 29, т. 3. C. 177-184.

31. Сарычева А.И. Новые данные по стратиграфии юрских отложений Волгоградской области // Тр. Волгогр. НИИНГ. 1964. Вып. 3. С. 48-58.

32. Азбель А.Я., Стариева Г.Н., Яковлева С.П. Восточные районы Восточно-Европейской платформы и Мангышлак // Биостратиграфия верхнеюрских отложений СССР по фораминиферам / Под ред. А.А. Григялиса. Вильнюс, 1982. C. $81-88$. 